綜説

$$
\begin{gathered}
\text { プロトテカという微生物 } \\
\text { 椿 啓 介 } \\
\text { 筑波大学生物科学系 }
\end{gathered}
$$

Key words : プロトテカ (Prototheca)

プロトテカPrototheca といら生物は人間执よ び動物のプロトテカ症 protothecosis を掞こす一 つの微生物として最近になって注目をあびてきた が，未だに生物学上の分類位置が判然とされてい ない。この属は 1894 年に Krügerによりり設立され たもので，種類として当時は 2 種，すなわち $P$. zopfii Krüger と P. moriformis Krüger が設けら れた. しかし Krüger は属の設立当時, この微生物 は菌類近似のものとして記載しただけであった。 その後, Saccardo (1895) がはじめてプロトテカ 属を菌類の範囲内に入れ, 子囊菌類のエンドミセ ス科のものとして Sylloge Fungorum 11 巻に記 載している. 円い細胞の中に入っている内生胞子 を子囊胞子と思ったのであろう. 次いで West (1916)はこれは菌類ではなく藻類に入れるべきも のとしてクロレラなどをふくさ単細胞藻類の緑藻 綱 Chlorophyceae のオーキスチス科 Oocystaceae に移した。藻類学者である Fritsch (1948) は“Krügerのプロトテカ属は色素を失ったクロ レラ以外の何物でもない.......”とのべている. 一 方, Redaelli とCiferri (1935，1936) はプロトテ カに色素体の欠けている点を重視して緑藻類のク ロレラ科のそばにプロトテカ科 Protothecaceae を設けたPrintz（1927）の説に賛同しており， Ciferri (1957) はその後 Prototheceae とあらため た.

以上のように藻類に入れる説，菌類と藻類との

別刷請求先：椿 啓介

- 現 $\overline{\mathbf{T}} 274$ 船橋市習志野台 $7-7-1$ 日本大学薬学部生物研究室
中間に拉く説などが入り乱れているが決定的な意 見は未だに出されて扔らず，乙たがって本属を取 扱った報文もきわめて多方面にわたっている（末 尾文献集参照).

\section{プロトテカの特性}

属の特徵：無色, 細胞は球形, だ円形, 長円形 など円味をおびた単細胞で出芽増殖はせず，成熟 するにしたがってふくらみ，内部に 2 8（20） 個の内生胞子 autosporeを形成した胞子囊 sporangium となる (Fig. 1.). 内生胞子は，未熟のと きは相互に接して畟形のように角ばっているが成 熟すると卵一球形となり，大ささは大凡径 10 20 (25) $\mu \mathrm{m}$ ，やがて胞子囊の外壁が破れ，内 生胞子は遊離して栄養細胞 vegetative cell とな り，同様な生活史をたどる，色素体を欠き，有性 生殖はみられない，寒天培地上のコロニーは白色 〜淡クリーム色で酵母状を呈す (Fig. 2, 3).

基準種は Prototheca zopfii Krüger (1894)

分布：現在までの報告によると樹液，尿，爪， じゃがいもの皮, 河川, 排水処理場の水溝, 牛の 乳房炎患部，魚内臓などである。このように自然 界に打ける分布は広く，日本に拈いては筆者らが はじめて樹液(ミズナラなど)などから分離(1959) して 1 新種 P. wickerhamii を設立し, 次いで廃水 処理槽から報告した(1987).プロトテカはその比 較的単純な形態と一見酵母様の培地上コロニ一の ため見逃され易いが，プロトテカ症や廃水処理施 設などから今後分離例は増加することであろう。

以上は主に自然界における分布であるが最近注 目されてきたプロトテカ症がある。これは牛に発 


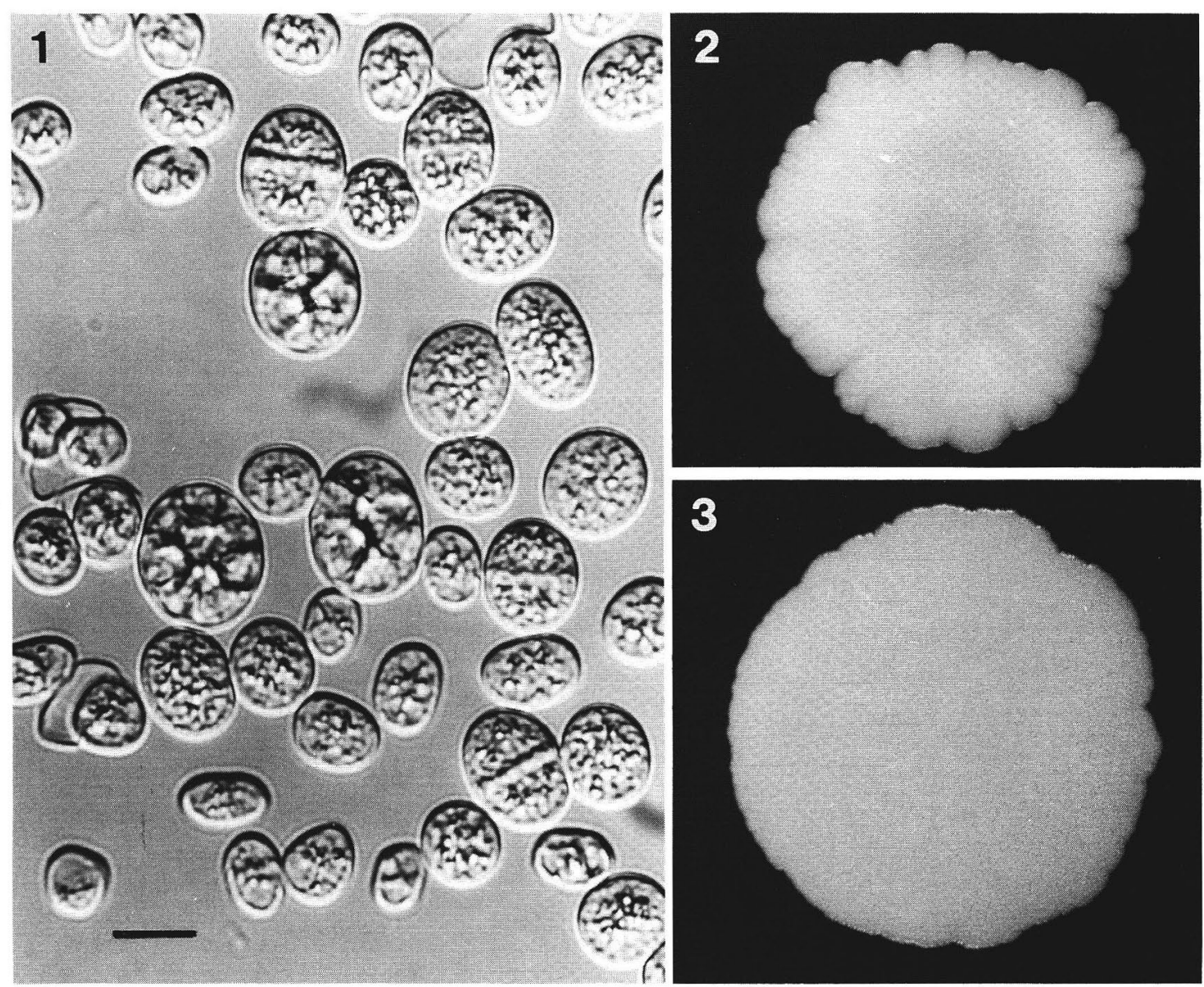

Fig. 1. Vegetative cells, sporangia and autospores of Prototheca zopfii, scale= $10 \mu \mathrm{m}$.

Fig. $2 \& 3$. Colonies of P. zopfii on malt yeast-extract agar and potato dextrose agar plates $(\times 4)$.

熱, 感染分房の発赤・腫張・硬結をともなら乳房 炎で原因微生物として日本からも池田ら（1985） により見出されており, 詳細な薬剤感受性, 病理 学的知見が報告されている.牛の泌乳量が激減し， 長期にわたる重度の病状を持続するので家畜衛生 上で重要であり，また，未だ日本では報告がない ようであるが人体感染の危険性もあるので今後注 意すべき微生物のひとつであろう。外国では牛の 他, 古くから人体, 犬, 猫, 鹿などにプロトテカ 症が報告されて招り，最も多いのは犬の症例で重 度の感染症とされている。

分類：上述のようにプロトテカの分類位置に関
してはさまざまな意見が出ているが決定的なもの は未だ見当らない，種の区別にしても過去にいろ いろな分類基準が提案されているものの，胞子囊 の大きさをとっても種がオーバーラップし, 培地 や湿度によっても差があり, 内生胞子の数も条件 によって異なってくるので形態のみによる判別は きわめて難しい。

現在までに発表されてきた種を年代順に列記す ると次の如くである。

(種名)

Prototheca zopfii Krüger

（分離源）（発表年）

P. moriformis $\mathrm{K}$.

樹液 1894

樹液 1894


P. portoricensis Ashford, Ciferri \& Dalmau

$\rightarrow$ P. zopfii

P. portoricensis var. trispora Ashf., Cif \& 人体

Dalmau

$\rightarrow$ P. zopfii

P. ciferri Negroni \& Blaisten

$\rightarrow$ P.zopfii

P. wickerhamii Tubaki \& Soneda

廃水溝 1959

P. segbwema Davies, Spencer \& Wakelin

人体 1964

$\rightarrow P$. zopfii

P. stagnora W.B. Cooke 廃水処理場

1968

P. ubrizsyi Zsolt \& Novak

1968

$\rightarrow$ P. zopfii

P. filamenta Arnold \& Ahearn

人体

1972

Nadakavukaren らにより菌類に移された。

\section{P. salmonis Gentles \&}

Bond

鮭内臓 1977

形態学的研究に引続き, プロトテカの培養が酵 母様のコロニーを示す点, また, 過去のデータか ら炭素源の資化性が種によって異なる点などから プロトテカの分類に酵母分類の手法が適用され た. Arnold と Ahearn は培養保存されていたプロ トテカ 23 株を用いて生理的性質を検討した結果, 炭素源の資化性から 5 種に整理して検索表を示し た．現在のところ，この検索表の一部を修正すれ ば種の同定は可能である。資化性試験に使用した 炭素源は dextrose, sucrose, maltose, lactose, galactose, xylose, levulose, raffinose, trehalose, methanol, ethanol, $n$-propanol, iso-propanol, $n$-butanol, tert-butanol, $n$-pentanol, isopentanol, hexanol, cyclo-hexanol, phenol, glycerol, sorbitol, inositol, dulcitol, erythritol な ぞ.すべての種は dextrose, levulose, galactose, ethanol, $n$-butanol, iso-butanol, iso-pentanol, hexanol, glycerol を消化する. 反対にすべて maltose, lactose, cellobiose, xylose, raffinose な ぞの糖を資化し得ない点にも特徵があり, sucrose, trehalose, $n$-propanol の資化性で種を判 別することができる，全種にビタミン要求性があ り thiamin が発育に必要である. Arnold と Ahearn (1972) が提案した検索表は以上の資化性 を基本としてできたものであるが，そのなかの $P$. filamentaは後に Nadakavukaren ら（1975）に よって明らかに真菌であることが示されたので, ここではプロトテカ属から外して拈く.最も新し く設立された種として淡水の鮭に内臓疾患を抢こ すP. salmonis があり，これを追加して現段階に おける種の検索表をつくってみると以下のように なろら。

[プロトテカ属の種検索表]

1.コロニーは白色， $24^{\circ}$ で発育 …………....2 コロニーは成熟すると黄色となり $24^{\circ} て ゙$ 発 育しない ………………..... salmonis

2. Sucrose を資化する ………P. stagnora Sucrose を資化しない ………………....

3. Trehalose と資化する ………………4 Trehalose を資化しない .........P. zopfii

4. n-propanol を資化する ‥P. moriformis n-propanol を資化しない.......

\section{….P. wickerhamii}

な招 $P$. moriformis はSudmanにすれば $P$. zopfii に含ませるべきものとされているが，ここ では別種として扱った。

このように一応の検索はできるが, 未だ系統学 的見地から不明な点が多く, 分類学的な検討にし ても酵母研究者が少しふれたていどで, 藻類学者 にも研究対象とされていないようである. 成書 Dictionary of the Fungiに拉いても achloric algae ?として載せられているていどの扱いであ る.プロトテカ症の増加することも予想され, Sudman (1974) のプロトテカ症総説に打いてもその 病原性，治療対策にふれているところである。最 近目覚ましく発展をとげている生化学的手法, 化 学分類の知見をとり入れ，この不鮮明な生物の ベールをはがしたいものである。

最後に筆者が知り得た限りのさまざまな分野で 
発表された文献を列記して参考に供する。

\section{文 献}

1) Anderson, E.H.: Nature of the growth factor for the colorless alga Prototheca zopfii. J. Gen. Physiol., 28 : 287-296, 1945.

2) Anderson, E.H.: Studies in the metabolism of the colorless alga Prototheca zopfii. J. Gen. Physiol., 28 : 297-327, 1945.

3) Arnold, P. and Ahearn, D.G.: The systematic of the genus Prototheca with a description of a new sepcies $P$. filamenta. Mycologia, $64: 265$ -275, 1972.

4) Ashford, B.K., Ciferri, R. and Dalmau, L.M.: A new species of Prototheca and a variety of the same isolated from the human intestine. Arch. f. Protistenk, 70:619-638, 1930.

5) Baker, H.A.: The metabolism of the colorless alga, Prototheca zopfii. J. Cell. Comp. Phys., 7 : 73-93, 1935.

6) Bodenhoff, F. and Madsen, P.S.: Bovine protothecosis. A brief report of the cases. Acta Path. Microbiol. Scand. Sect. B, $86: 51-52$, 1978.

7) Buyukmihci, N., Rubin, L.F. and DePaoli, A.: Protothecosis with ocular involvement in a dog. J.A.V.M.A., 167 : 158-161, 1975.

8) Ciferri, O.: Thiamine-deficiency of Prototheca, a yeast-like achloric alga. Nature 178: 1475 -1476, 1956.

9) Ciferri, O.: Metabolismo comparativo della Prototheca e'delle mutanti achloriche di Chlorella. Giornale de Microbiol., 3 : 97-108, 1957.

10) Ciferri, R., Montemartini, A. and Ciferri, O.: Caraterische morfologiche $\mathrm{e}$ assimilative $\mathrm{e}$ speciologia della Protothecae. Nuov. Ann. Log., $8: 554-563,1957$.

11) Coloe, P.J. and Allison, J.F.: Protothecosis in a cat. J.A.V.M.A., 180:78-79, 1982.

12) Cooke, W.B.: Studies in the genus Prototheca. I. J. ELisha Mitchel Sci. Soc., $84: 213-216$, 1968.

13) Cooke, W.B.: Studies in the genus Prototheca II. J. Elisha Mitchel. Sci. Soc.. $84: 217-220$, 1968.

14) Conte, M.V. and Pore, S.R.: Taxonomic implication of Prototheca and Chlorella cell wall polysaccharide characterization. Arch. Microbiol., 92 : 227-233, 1973.

15) Cox, G.E., Wilson, J.D. and Brown, P.: Protothecosis. A case of disseminated algal infection. The Lancet, Aug. 17 : 379-382, 1974.
16) Davies, R.R., Spencer, H. and Wakelin, P.V.: A case of human protothecosis. Trans. Royal Soc. Trop. Med. \& Hyg., 58 : 448-451, 1964.

17) DeCamargo, Z.P. and Fishman, O.: Use of morpho-physiological characteristics for the diffrentiation of the species of Prototheca. Sabouraudia $17: 275-278,1979$.

18) DeCamargo, Z.P., Fishman, O. and Silva, M.R. R.: Experimental protothecosis in a laboratory animals. Sabouraudia $18: 237-240,1980$

19) Dion, W.M.: Bovine mastitis due to Prototh eca zopfi. Can. Vet. J., 20 : 221-222, 1979.

20) El-Ani, A.S.: Life cycle and variation of Prototheca wickerhamii. Science 156:1501 -1503, 1967.

21) Feo, M.: Cinco cepas de Prototheca de origen human. Mycopath. Mycol. Appl., 46 : 53-59, 1972.

22) Fetter, B.F., Klintworth, G.K. and Nielsen, H. S.: Protothecosis. Algal infection in human with Fungi-actinomycetes and algae. Edit. Baker N.Y. 1971, 1081-1093, 1971.

23) Finnie, J.W. and Coloe, P.J.: Cutaneous protothecosis in a cat. Aus. Vet. J., 23:307 -308, 1981.

24) Frank, N., Ferguson, C.C., Cross, R.F. and Redman, D.R.: Prototheca, a cause of bovine mastitis. Am. J. Vet. Res., 30 : 1785-1974, 1969.

25) Frese, V.K. and Gedek, B.: Ein fall von protothecosis beim reh. Berl. Munch. Tieraerztl. Wochenschr, 81 : 171-178, 1968.

26) Gentles, J.C. and Bond, P.M. : Protothecosis of Atlantic salmon. Sabouraudia, 15 : 133-139, 1977.

27）池田輝雄注か：Prototheca zopfii に上る牛乳房炎 について. 真菌と真菌症, $26: 221-227,1985$.

28) Joshi, K.R., Gavin, J.B. and Wheeler, E.E.: The ultrastructure of Prototheca wickerhamii. Mycopath, 56: 9-13, 1975.

29) Dickinson, R.O.: Protothecosis in a cat. First record case. Sabouraudia, 14:281-286, 1976.

30) Klintworth, G.K., Fetter, B.F. and Nielsen, J. R. : Protothecosis, an algal infection: report of a case in man. J. Med. Microbiol., 1:211 $-216,1968$.

31) Kockova-Kratchvilova, A. and Havelkova, M.: Prototheca hydrocarbonea $\mathrm{n}$. sp. Life cycle, metabolism and fine structure. Z. Allg. Mikrobiol., $14:$ 123, 1974.

32) Krüger, W.: Kurz Characteristik einiger niederen Organismen in Saftflüsse de Laub- 
baüme. 1. Ueber einen neuen Pilz-typus, repräsentiert durch die Gattung Prototheca ( $P$. moriformis et $P$. zopfii). 2. Ueber zwei aus Saftflüssen rein gezüchtet Algen., Hedwigia $33: 241-266,1894$.

33) Lloyd, D. and Turner, G.: The cell wall of Prototheca zopfii. J. Gen. Microbiol., 50:421 $-427,1968$.

34) Manners, D.J. and Pennie, I.E.: The molecular structure of a glucan and galactan synthesized by P. zopfii. Carbohyd. Res., $29: 63-77$, 1973.

35) Migaki, G., Font, R.L., Sauer, R.M., Kalpin, W. and Miller, R.L.: Canaine protothecosis. Review of the literature and report of an additional case. J.A.V.M.A., $181: 794-797,1982$.

36) Migaki, G., Garner, F.M. and Imes, G.D. Jr.: Bovine protothecosis. A report of three cases. Path. Vet., 6: 444-453, 1969.

37) Nadakavukaren, M.J. and McCracken, D.A.: Prototheca. An alga or a fungus?, J. Phycol., 9 : 113-116, 1973.

38) Nadakavukaren, M.J. and McCracken, D.A.: An ultrastructural survey of the genus Prototheca with special reference to plasmids. Mycopath, 61 : 117-119, 1977.

39) Negroni, P. and Blaisten, R.: Estudio morfologicoy fisiologico de una nueva especie de Prototheca, $P$. ciferrii. n. sp. aislada de epidermis de papa. Mycoath, $3: 94-104,1941$.

40) Nosanchuk, J.S. and Greenberg, R.D. : Protothecosis of the olecranon bursa caused by acholric algae. Am. J. Clin, Pathol., 59: 567 -573, 1973.

41) Padhye, A.A., Baker, J.G. and D'Amato, R.F.: Rapid identification of Prototheca species by the API 20C system. J. Clin. Microbiol., 10:579 $-582,1979$.

42) Pore, R.S.: Nutritional basis for relating Prototheca and Chlorella. Can. J. Microbiol., $18:$ 1175-1177, 1972.

43) Povey, R.C., Austwick, P.K.C., Pearson, H. and Smith, K.C.: A case of protethecosis in a dog. Path. Vet., 6 : 396-402, 1969.

44) Roger, R.J.: Protothecal lymphadentis in an ox. Aust. Vet., 50 : 281-282, 1974.

45) Schiefer, B. and Gebek, B.: Zum verhalten von Prototheca species im gewebe von saugetieren. Berl. Munch. Tieraertztl. Wo- chpenschr., $81: 485 \sim 490,1968$.

46) Segal, E., Padhye, A.A. and Ajello, L.: Susceptibility of Prototheca species to antifungal agents. Antimicrob. Agents and Chemoth., 10 : 75-79, 1976.

47) Smith, G.C.: Ultrastructural study of Prototheca salmonis and comparison with known isolates of Prototheca. Mycopath., 71 : 95-101, 1980.

48) Sonck, C.E. and Koch, Y.: Vertreter de Gattung Prototheca als schmarotzer auf der Haut. Mykosen, 14: 475-482, 1971.

49) Sudman, M.S.: Protothecosis. A critical review. A.J.C.P., 61 : 10-19, 1974.

50) Sudman, M.S., Majka, J.A. and Kaplan, W.: Primary mucocutaneous protothecosis in a dog. J.A.V.M., $163:$ 3172-3373, 1973.

51) Sudman, M.S. and Kaplan, W.: Identification of the Prototheca species by immunofluorescence. Appl. microbiol., 25 : 981-990, 1973.

52) Sudman, M.S. and Kaplan, W.: Antigenic relationships between Chlorella and Prototheca spp. Sabouraudia 12 : 364-370, 1974.

53) Tindall, J.P. and Fetter, B.F.: Infections caused by acholoric algae (protothecosis). Arch. Dermat., 104 : 490-500, 1971.

54) Tubaki, K. and Soneda, M.: Cultural and taxonomic studies on Prototheca. Nagaoa, 6 : 25-34, 1959.

55）椿啓介ほか：廃水処理槽から分離された Prototheca. 防菌防徽誌, $15: 487-490,1987$.

56) Turner, G. and Lloyd, D.: The chemical composition and structure of the cell wall of Prototheca zopfii. Biochem. J., 99 : 55-56, 1966.

57) Van Kruiningen, H.J., Garner, F.M. and Schiefer, B.: Protothecosis in a dog. Path. Vet., $6: 348-354,1969$.

58) Van Kruiningen, H.J.: Prototthecal enterocolitis in a dog. J.A.V.M.A., $157: 56-63$, 1970.

59) Vorisek, J. and Kockova-Kratochvilova, A.: Ultrastructural distribution of polysaccharides in Prototheca hydrocarbonea. Z. Allg. Mikrobiol., $15: 203,1975$.

60) Zsolt, J. and Novak, K.: A new species of yeast-like achloric algae, Prototheca ubrizsyi, n. sp. Act. Phytopath. Acad. Sci. Hung., 3 $: 423$ $-430,1968$. 


\title{
A Review of the Genus Prototheca
}

\author{
Keusuke Tsubaki \\ College of Pharmacy, Nihon University, Narashinodai 7-7-1, Funabashi-shi, Chiba 274, Japan
}

The genus Prototheca is composed of microscopic achlorophyllous organisms has a life cycle similar to that of Chlorella and is widespread in nature. Prototheca species are considered adventitious pathogens. The genus is reviewed on the basis of life cycle, morphology and physiology. Colony morphology and physiological identification keys are given. All eleven known epithets published on Prototheca are listed and a literature review is provided. 